\title{
Characteristics of lime produced from limestone containing diatoms
}

\author{
Hasan Böke *, Özlem Çizer, Başak İpekoğlu, Elif Uğurlu, Kerem Şerifaki, Gülcan Toprak \\ Architectural Restoration Department, İzmir Institute of Technology, 35430 İzmir, Turkey
}

Received 27 January 2006; received in revised form 13 December 2006; accepted 20 December 2006

Available online 31 January 2007

\begin{abstract}
In this study lime binder used in stone and brick masonry mortars of some historic Ottoman baths was examined to understand whether the binders were hydraulic or not. For this purpose the mineralogical and elemental compositions and the microstructure of lime binder were determined by XRD, SEM-EDS and TGA analyses. The results indicate that the lime used in the brick dome mortars of Ottoman baths was hydraulic. Taking into account the kiln and fuel conditions of the 15th century, the possibility of obtaining hydraulic lime at relatively low temperature was examined. For this purpose limestone containing diatoms was heated at a relatively low temperature $\left(850^{\circ} \mathrm{C}\right)$, then slaked and carbonated. After heating and slaking, calcium silicate giving hydraulicity to the lime was indicated by XRD and SEM-EDS analyses. These results show that the production of hydraulic lime at a relatively low calcination temperature $\left(850^{\circ} \mathrm{C}\right)$ was possible with 15 th century kilns.
\end{abstract}

(C) 2006 Elsevier Ltd. All rights reserved.

Keywords: Limestone; Diatoms; Calcium silicate; Hydraulic lime; Historic buildings

\section{Introduction}

Mortars used for bedding and jointing masonry units and rendering masonry surfaces are composed of binders and aggregates [1,2]. Historically, different types of binder materials have been used in the construction of masonry buildings. Mud mortars are the oldest documented mortars and were used in the construction of the first collective settlements in Mesopotamia 10,000 years ago [1]. Gypsum mortar is a binder long used in the brick vaults and arches due to its quick setting and high mechanical strength $[1,3]$. Lime mortars have been the most widely used in the construction of the buildings since their first known use in Egypt in $4000 \mathrm{BC}[2,4]$.

Lime mortars can be classified as non-hydraulic and hydraulic. Non-hydraulic lime mortars are produced by mixing slaked lime with aggregates and harden by evaporation and carbonation of lime due to carbon dioxide in the air. Hydraulic lime mortars are produced either by mixing

\footnotetext{
${ }^{*}$ Corresponding author. Tel.: +90 232 7507035; fax: +90 2327507012. E-mail address: hasanboke@iyte.edu.tr (H. Böke).
}

lime with pozzolans containing amorphous active silicates and aluminates or by developing hydraulic phases through the calcination of silica rich limestone directly quarried or synthetically mixed. Hydraulic lime mortars harden by evaporation, carbonation of lime and the reaction between lime and pozzolans or the hydraulic phases in the presence of water. This reaction produces calcium silicate hydrates and calcium aluminate hydrates, allow for setting under water and impart higher earlier strength to the hydraulic lime mortars [5]. For this reason, such mortars have been extensively used in the construction of foundations placed in waterlogged grounds and for drainage systems, cisterns, and bridges since ancient Greek period [1,2]. Romans successfully improved on masonry structures the use of hydraulic lime mortars produced by combining lime and pozzolans [1,2].

Determination of historic lime mortar characteristics became an important subject in the second half of the 20th century. The studies on historic lime mortars and plasters are compiled by Hansen et al. [6] in an extensive bibliography and provide a source for conservators and conservation scientists. 
Among the studies of historic lime mortars, the achievement of hydraulic properties of historic mortars is usually described as the process of mixing pozzolans with high calcium lime [7-12]. However, the possibility of the use of calcined hydraulic lime in historic mortars has not been thoroughly considered.

The first production of calcined hydraulic lime is documented around the second half of the 18th century [4]. This type of lime is obtained by the calcination of limestone with high amounts of clay substances, forming calcium and aluminum silicates at temperatures between $950{ }^{\circ} \mathrm{C}$ and $1250{ }^{\circ} \mathrm{C}$. It was known that such temperatures could not be reached before the 18 th century. Therefore the possibility of achieving the hydraulic properties of lime at relatively low temperatures through heating of limestone containing diatoms which are mainly composed of amorphous silica has not been taken into consideration.

In this study the hydraulic characteristics of lime mortars used in the walls and brick domes of some Ottoman baths are examined to determine whether hydraulicity of the mortars originates by mixing pozzolans with lime or by the use of hydraulic lime. The results of this study indicate that the lime used in the brick dome mortars of Ottoman baths was hydraulic. Taking into account the kiln conditions of the 15 th century, the possibility of obtaining hydraulic lime at relatively low temperature was examined. For this purpose limestone containing diatoms was heated at a relatively low temperature $\left(850^{\circ} \mathrm{C}\right)$, then slaked and carbonated. After heating and slaking of limestone, formation of hydraulic products was indicated by XRD, SEM, EDS and TGA analyses.

\section{Materials and method}

The study is composed of two phases. First phase examines the general characteristics and the hydraulic properties of lime binders of the mortars used in the walls and brick domes of some Ottoman baths. Based on the findings of the first phase, second part of the study investigated the possibilities of obtaining hydraulic lime from limestone

Table 1

Density, porosity, uniaxial compressive strength (MPa) and lime aggregate ratio values of mortars

\begin{tabular}{lllcl}
\hline Sample & Density & Porosity & C.S. (MPa) & L/A \\
\hline Se-S & $1.52 \pm 0.04$ & $40.70 \pm 1.56$ & \multicolumn{1}{c}{-} & 0.7 \\
Du-S & $1.51 \pm 0.03$ & $41.85 \pm 0.30$ & $5.3 \pm 1.7$ & 0.6 \\
Ul-S & $1.84 \pm 0.03$ & $26.82 \pm 1.56$ & $7.4 \pm 4.7$ & 0.3 \\
He-S & $1.50 \pm 0.06$ & $36.94 \pm 5.89$ & $9.7 \pm 1.4$ & 0.4 \\
Ka-S & $1.69 \pm 0.04$ & $32.80 \pm 1.43$ & $4.2 \pm 0.5$ & 0.7 \\
Du-B & $1.48 \pm 0.08$ & $38.60 \pm 6.79$ & $14.7 \pm 4.5$ & 0.4 \\
Ul-B & $1.72 \pm 0.07$ & $31.85 \pm 2.33$ & $21.0 \pm 3.0$ & 0.4 \\
He-B & $1.59 \pm 0.04$ & $35.07 \pm 1.77$ & $10.5 \pm 2.6$ & 0.3 \\
Ka-B & $1.40 \pm 0.03$ & $43.46 \pm 1.14$ & $8.8 \pm 1.0$ & 0.7 \\
\hline
\end{tabular}

Se: Seferihisar bath; Du: Düzce bath; Ul: Ulamış bath; He: Hersekzade bath; Ka: Kamanlı bath; S: Stone masonry mortar; B: brick masonry mortar; C.S.: compressive strength; L/A: lime/aggregate. containing diatoms by calcining at relatively low temperature $\left(850^{\circ} \mathrm{C}\right)$.

\subsection{Sampling of lime mortars}

First phase of this study was to understand whether the lime binders used for masonry mortars of historic Ottoman bath constructions were hydraulic or not. Respectively, lime mortar samples were collected from the walls and domes of five historic Ottoman baths constructed in the

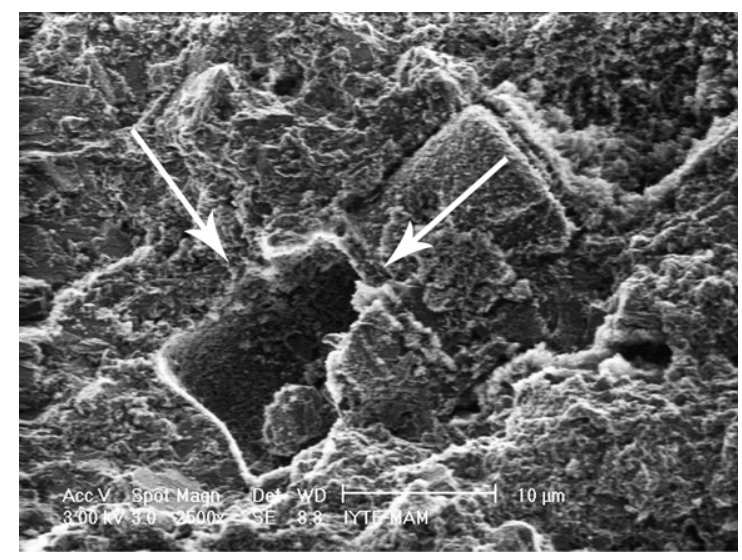

Fig. 1. SEM image of a cone shape diatom shown by arrow at the limestone aggregate.
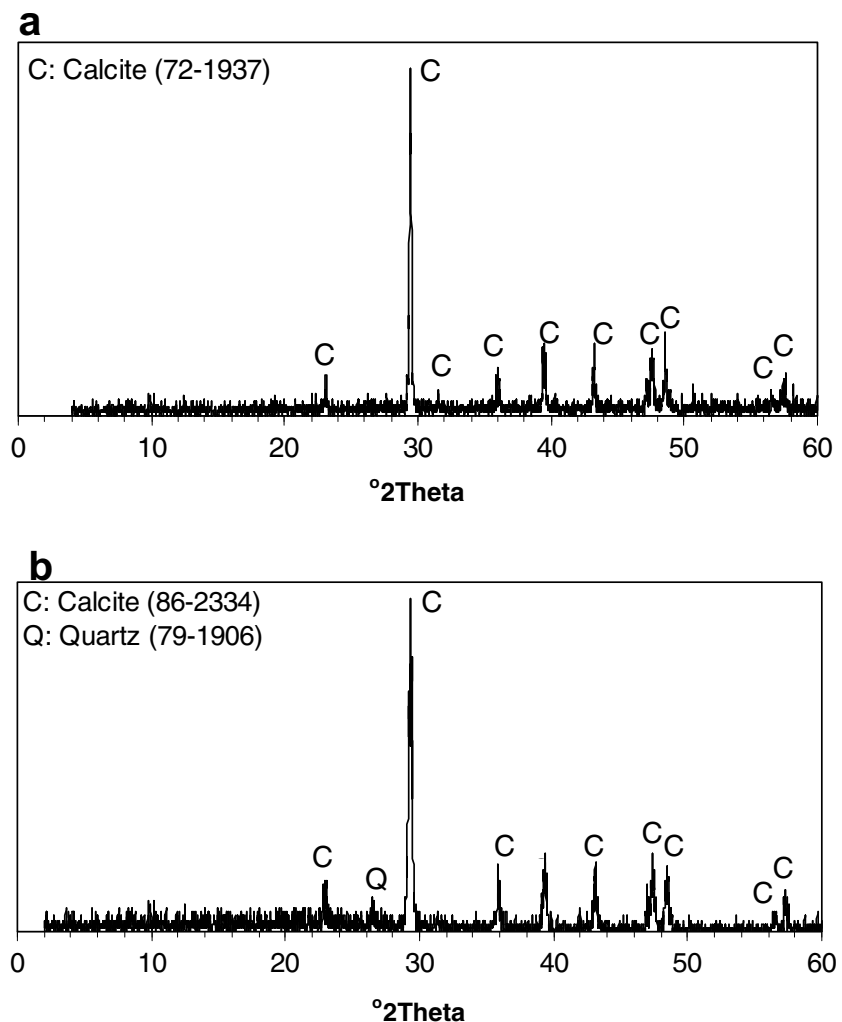

Fig. 2. Typical XRD patterns of white lumps in stone (a) and brick masonry (b) mortars. 
15th century near İzmir, Turkey (Table 1). During the second half of the 14th and 15th centuries a large number of baths were built in Anatolia and the Balkans under Ottoman rule [13]. The primary materials used in these buildings were stone and brick, with lime mortar as the binder [14]. Rubble and cut stones are the major structural materials in the walls. Brick was generally used in the upper parts of the masonry, such as arches, vaults, and domes.

\subsection{Analysis of lime mortars}

The basic physical properties, microstructure, chemical and mineralogical compositions of the mortars were examined through several analyses. Bulk densities and porosities of the mortars were determined by measuring the dry, water saturated under vacuum and hydrostatic weights [15]. Uniaxial compressive strength (UCS) test was carried out on at least three cubic specimens with side lengths about $5 \mathrm{~cm}$ [15]. The UCS analyses were done using a Shimadzu AG-I Mechanical Test Instrument. Lime and aggregate ratios were determined after the dissolution of carbonated lime in dilute hydrochloric acid. Mineralogical compositions of white lumps representing the binding material (lime) in the mortars were determined by FTIR and X-ray diffraction (XRD) analyses performed by a Magna-FTIR spectrometer 550 (Nicolet) and Philips Xpert Pro X-ray diffractometer. A stereomicroscope was used to separate white lumps from mortar matrices by using a small bistoury. Microstructures and chemical compositions of the white lumps were determined with a Philips
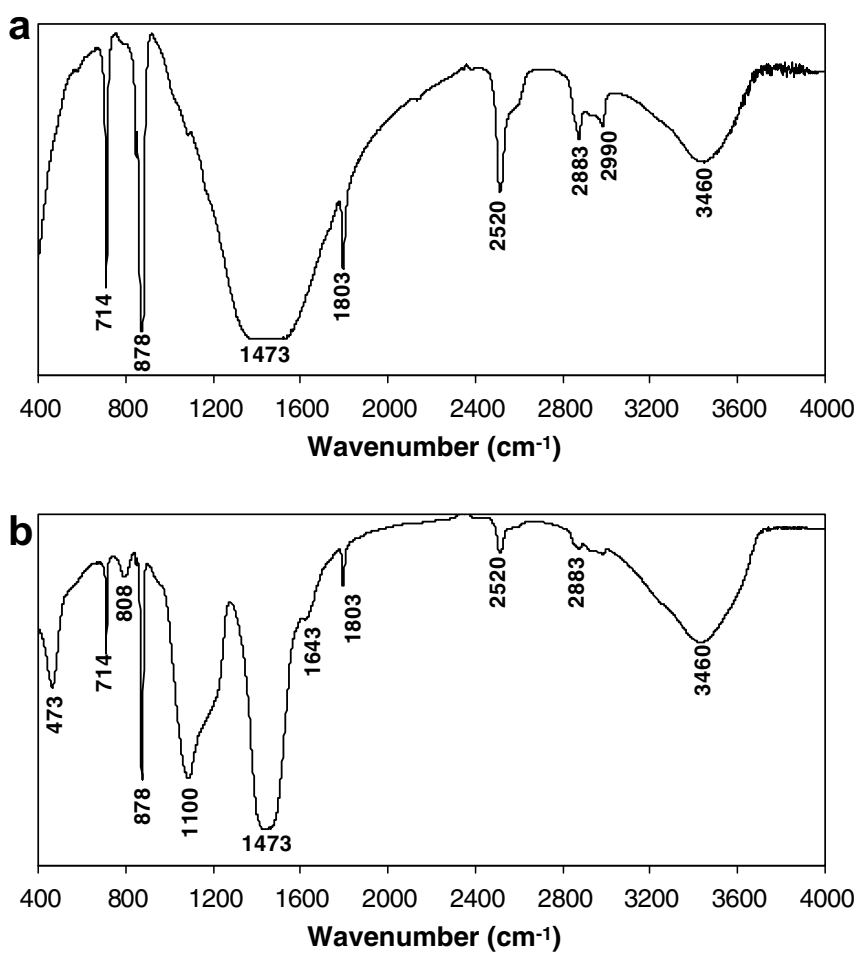

Fig. 3. Infrared spectrum of white lumps in stone (a) and brick masonry (b) mortars.
XL 30S FEG scanning electron microscope (SEM) coupled with X-ray energy dispersive system (EDS). Their hydraulic properties were evaluated by determining weight loss at the temperatures between 200 and $600{ }^{\circ} \mathrm{C}$ due to the loss of the structurally-bound water of hydraulic products, such as calcium silicate hydrates and calcium aluminate hydrates, and weight loss at the temperatures over $600{ }^{\circ} \mathrm{C}$ due to carbon dioxide released during the decomposition of calcium carbonates by using a Shimadzu TGA-51 [7].

\subsection{Sampling and calcination of limestone}

Based on the findings of the first phase, the study continued on investigating the possibilities of obtaining hydraulic lime at relatively low temperatures by the calcination of limestone. For this purpose, a type of limestone known to contain high amounts of diatoms was collected from masonry units of the walls of the historic Kamanlı Mosque [16]. This mosque is located nearby the Ottoman baths and dates to the same period as of the baths.

Calcination of limestone is carried out in a laboratory furnace. About $1 \mathrm{~g}$ of crushed limestone with $1 \mathrm{~mm}$ average particle size was calcined in the crucible at $850^{\circ} \mathrm{C}$ for $12 \mathrm{~h}$ and then cooled to room temperature in a decicator. Calcinated limestone (quicklime) was hydrated with distilled water in the glass beaker until lime putty was produced. Lime putty was then spread out on glass slides and carbonated for one month in the laboratory. During carbonation, lime was wetted with distilled deionised water. After one month, the samples were dried in an oven at $40^{\circ} \mathrm{C}$ for $24 \mathrm{~h}$.

Mineralogical compositions of the unheated and heated limestone, slaked and carbonated lime were determined by using a Philips X-pert X-ray diffraction (XRD) and a Spectrum BX II FTIR spectrometer (Perkin-Elmer). Chemical compositions and the microstructural properties of the unheated and heated limestone (quicklime), slaked and carbonated lime were determined by Philips XL 30S-FEG scanning electron microscope (SEM) equipped with X-ray energy dispersive system (EDS). The presence of hydraulic phases in the composition of carbonated lime was determined by using a Shimadzu TGA-51.

Table 2

$\%$ Elemental composition, cementation and hydraulicity indices of white lumps used in mortars and lime produced by limestone containing diatoms

\begin{tabular}{lrrlll}
\hline Samples & $\mathrm{CaO}$ & $\mathrm{SiO}_{2}$ & $\mathrm{Al}_{2} \mathrm{O}_{3}$ & $\begin{array}{l}\text { Hydraulicity } \\
\text { index }(\mathrm{HI})\end{array}$ & $\begin{array}{l}\text { Cementation } \\
\text { index }(\mathrm{CI})\end{array}$ \\
\hline $\mathrm{Du}-\mathrm{S}$ & 97.3 & 2.7 & $\mathrm{ND}$ & 0.03 & 0.1 \\
$\mathrm{Se}-\mathrm{S}$ & 96.2 & 2.5 & 1.3 & 0.04 & 0.1 \\
$\mathrm{He}-\mathrm{S}$ & 95.1 & 3.5 & 1.4 & 0.1 & 0.1 \\
$\mathrm{Ul}-\mathrm{S}$ & 64.9 & 28.3 & 5.6 & 0.5 & 1.3 \\
$\mathrm{Ka}-\mathrm{S}$ & 98.4 & 1.6 & $\mathrm{ND}$ & 0.02 & 0.05 \\
$\mathrm{He}-\mathrm{B}$ & 72.5 & 24.8 & 2.7 & 0.4 & 1.0 \\
$\mathrm{Du}-\mathrm{B}$ & 77.2 & 19.2 & 3.6 & 0.3 & 0.7 \\
$\mathrm{Ul}-\mathrm{B}$ & 85.1 & 11.2 & 3.7 & 0.2 & 0.4 \\
$\mathrm{Ka}-\mathrm{B}$ & 73.4 & 23.6 & 3 & 0.4 & 0.9 \\
Lime & 66.9 & 26.5 & 5.7 & 0.5 & 1.2 \\
\hline
\end{tabular}

ND: not detected. 


\section{Results and discussions}

\subsection{General characteristics of the mortars}

The binder/aggregate ratios of all mortars varied between 0.3 and 0.7 by weight (Table 1). Aggregates greater than $1180 \mu \mathrm{m}$ formed the largest fraction $(\sim 50 \%)$

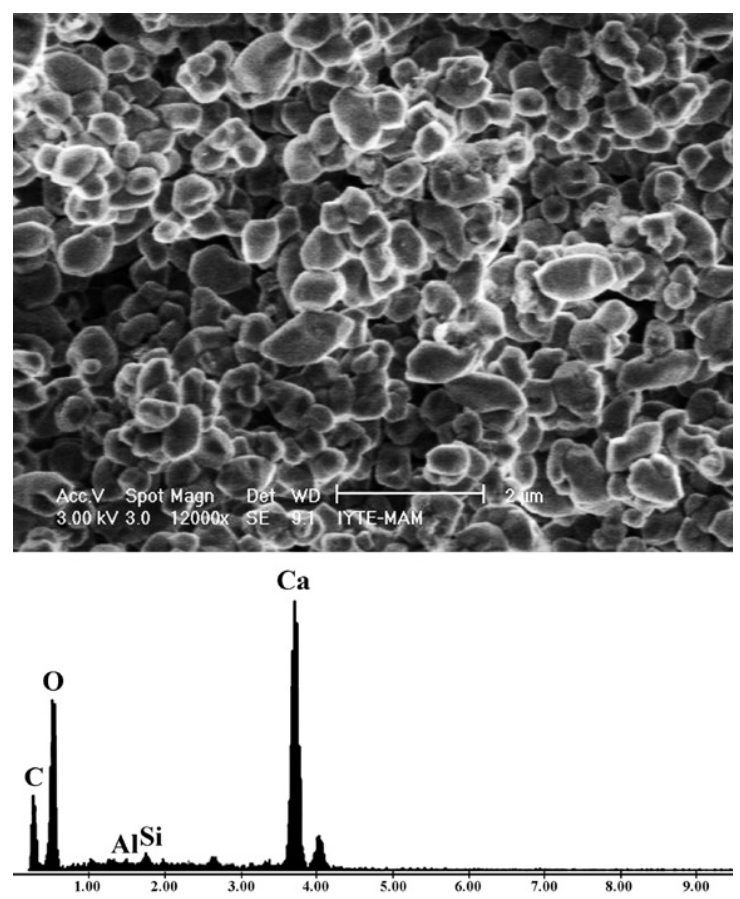

Fig. 4. Secondary electron image and EDS spectrum of micritic calcite crystals in a white lump of stone masonry mortars (Se-S).
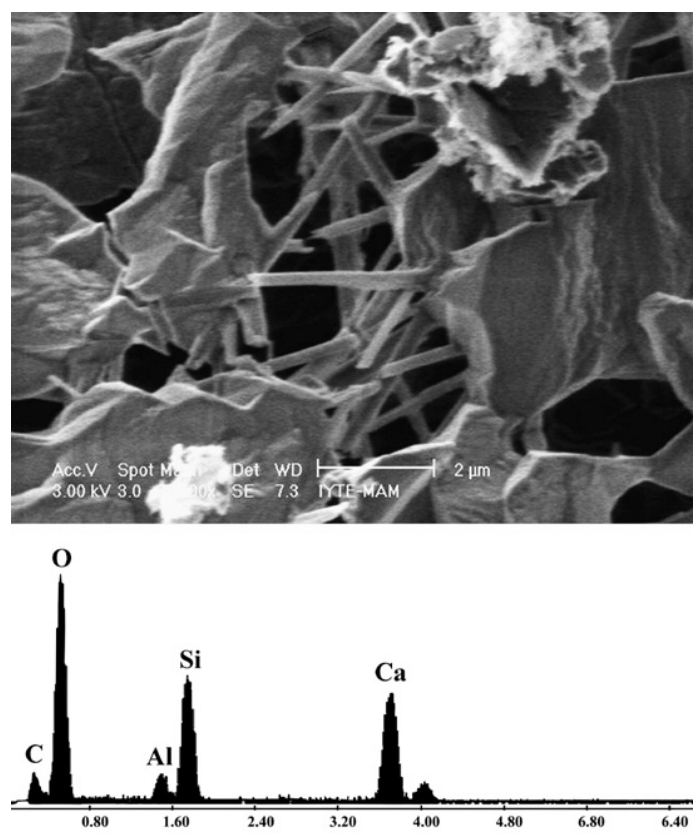

Fig. 5. Secondary electron image and EDS spectrum of fibrous network structure of a white lump in brick masonry mortars (U1-B). of the aggregates. Coarse and fine aggregates were siliceous rock fragments mainly composed of quartz, albite, potassium feldspar, muscovite and hematite. A very few pieces of limestone aggregates with diatoms were also observed in the mortars (Fig. 1). Their density and porosity values generally were between 1.4 and $1.5 \mathrm{~g} / \mathrm{cm}^{3}$ and $30-40 \%$, by volume, respectively (Table 1). All brick masonry mortars had relatively high compressive strength values, higher than $10 \mathrm{MPa}$ (Table 1). On the other hand, the compressive strengths of stone masonry mortars were generally less than $10 \mathrm{MPa}$.

These results indicate that stone and brick masonry mortars are similar based on the use of same type of natural aggregates, varied proportions of lime and aggregate ratios and thorough mixing of aggregates with lime until obtaining a uniform mixture. The mortars differed in their mechanical properties depending on their use in stone and brick masonry walls. Considering the compressive strength values in the relevant literature [17], all brick masonry mortars used in domes of the studied historic baths can be accepted as hydraulic mortars.

\subsection{Characteristics of the lime binder}

Small, white, round and soft fragments called "white lumps" were observed in all samples representing the binding material used in the mortars [18,19]. Mineralogical compositions of white lumps of all brick and stone masonry mortars were determined by XRD and FTIR analysis. In the XRD patterns of all white lumps, strong calcite peaks derived from carbonated lime were observed (Fig. 2). In their FTIR spectrum, the main $\mathrm{CaCO}_{3}$ bands at $714,878,1473,1803,2520,2883$ and $2990 \mathrm{~cm}^{-1}$ and the $\mathrm{O}-\mathrm{H}$ stretching $\left(3460 \mathrm{~cm}^{-1}\right)$, and $\mathrm{H}-\mathrm{O}-\mathrm{H}$ bending $\left(1643 \mathrm{~cm}^{-1}\right)$ vibrations were observed (Fig. 3a and b). In addition, $\mathrm{Si}-\mathrm{O}$ stretching vibrations at $1100 \mathrm{~cm}^{-1}$ and $970 \mathrm{~cm}^{-1}$, a band at $473 \mathrm{~cm}^{-1}$ due to the deformation of $\mathrm{SiO}_{4}$ tetrahedra, and a weak single band at $808 \mathrm{~cm}^{-1}$ possibly due to the disordered silica (Fig. 3b) were observed in the FTIR spectrum of the white lumps in brick masonry mortars $[20,21]$.

Presence of silicate peaks in IR spectrum of white lumps in brick masonry mortars but their absence in XRD spectrum differently than white lumps in stone masonry mortars shows the existence of amorphous or poor crystalline silica in their composition.

SEM-EDS analyses indicated that the white lumps of stone masonry mortars were composed of micritic calcite crystals containing high amounts of calcium oxide, over

Table 3

Classification of lime according to hydraulic and cementation indices

\begin{tabular}{lll}
\hline Lime & Hydraulic index & Cementation index \\
\hline Weakly hydraulic & $0.1-0.2$ & $0.3-0.5$ \\
Moderately hydraulic & $0.2-0.4$ & $0.5-0.7$ \\
Highly hydraulic & $<0.4$ & $0.7-1.1$ \\
\hline
\end{tabular}



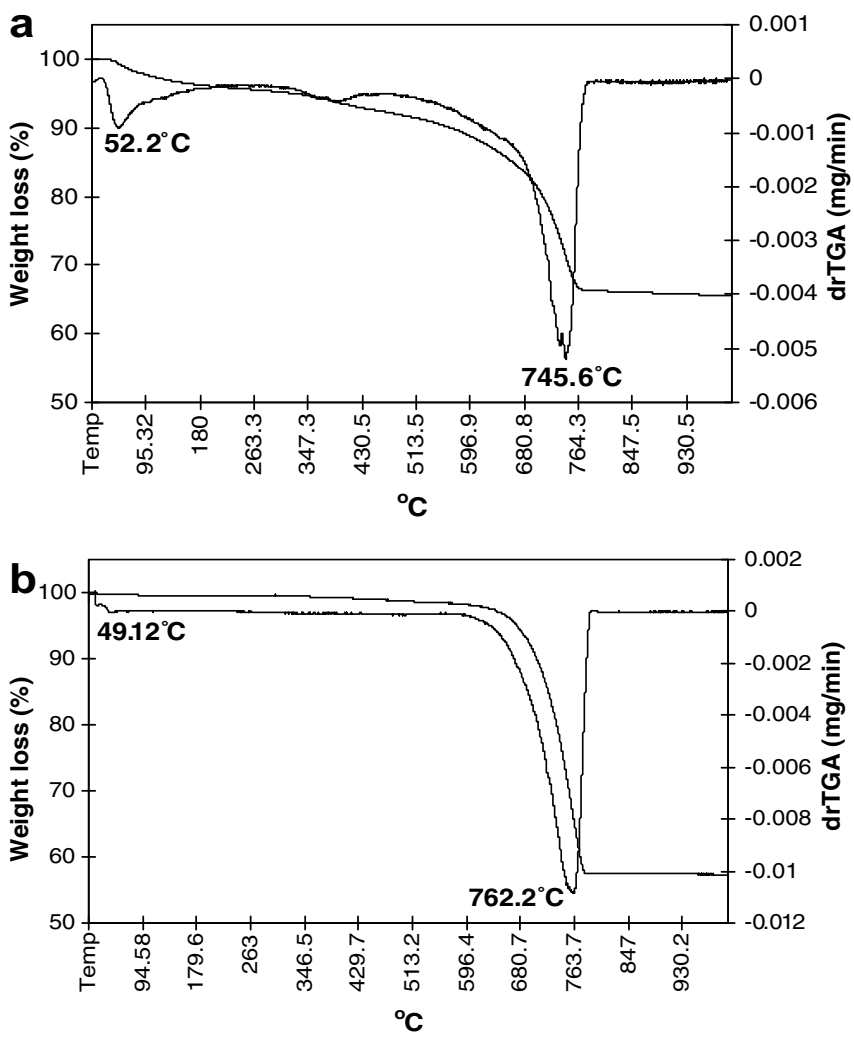

Fig. 6. TGA-drTGA graphs of a white lump in brick masonry (U1-B) mortars (a) and a white lump in stone masonry (Se-S) mortars (b).
90\% (Table 2, Fig. 4). On the other hand, white lumps of all brick masonry mortars were composed of larger calcite crystals connected with fibrous networks rich in silicon dioxide, up to $28 \%$ (Table 2, Fig. 5). High silicon oxide content and fibrous network structures show the presence of hydraulic reaction products such as calcium silicate hydrates in the white lumps of brick masonry mortars.

Hydraulic properties of lime can be determined by calculating hydraulic $(\mathrm{HI})$ and cementation $(\mathrm{CI})$ indices considering the chemical compositions of white lumps according to Boynton formula (Eq. (1) and (2)) [4]. The higher indices values indicate the more hydraulic character of lime (Table 3).

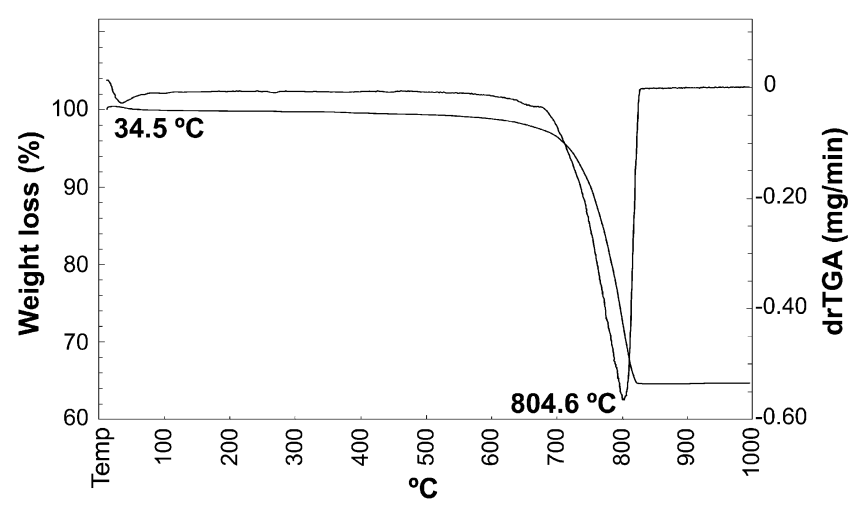

Fig. 8. TGA-drTGA graphs of limestone.
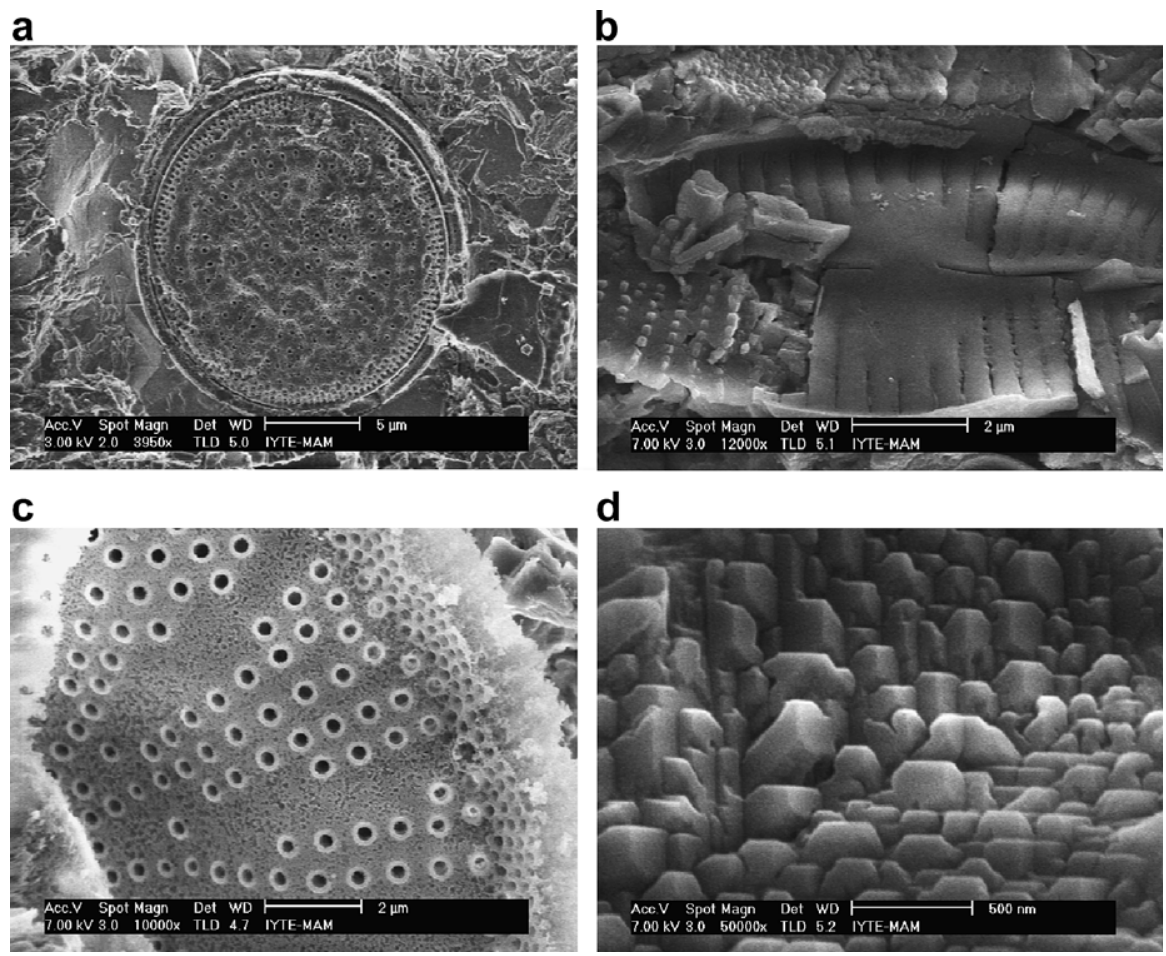

d

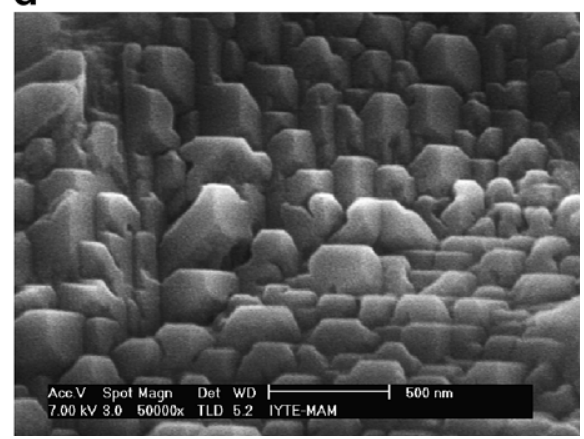

Fig. 7. Secondary electron images of a disk (a) and bow (b) shaped diatom frustules; small holes on their surfaces (c); precipitated small size of calcite crystals on the surface and the holes of the diatoms (d). 
$\begin{aligned} \mathrm{HI} & =\frac{\% \mathrm{Al}_{2} \mathrm{O}_{3}+\% \mathrm{Fe}_{2} \mathrm{O}_{3}+\% \mathrm{SiO}_{2}}{\% \mathrm{CaO}+\% \mathrm{MgO}} \\ \mathrm{CI} & =\frac{2.8 \% \mathrm{SiO}_{2}+1.1 \% \mathrm{Al}_{2} \mathrm{O}_{3}+0.7 \% \mathrm{Fe}_{2} \mathrm{O}_{3}}{\% \mathrm{CaO}+1.4 \% \mathrm{MgO}}\end{aligned}$
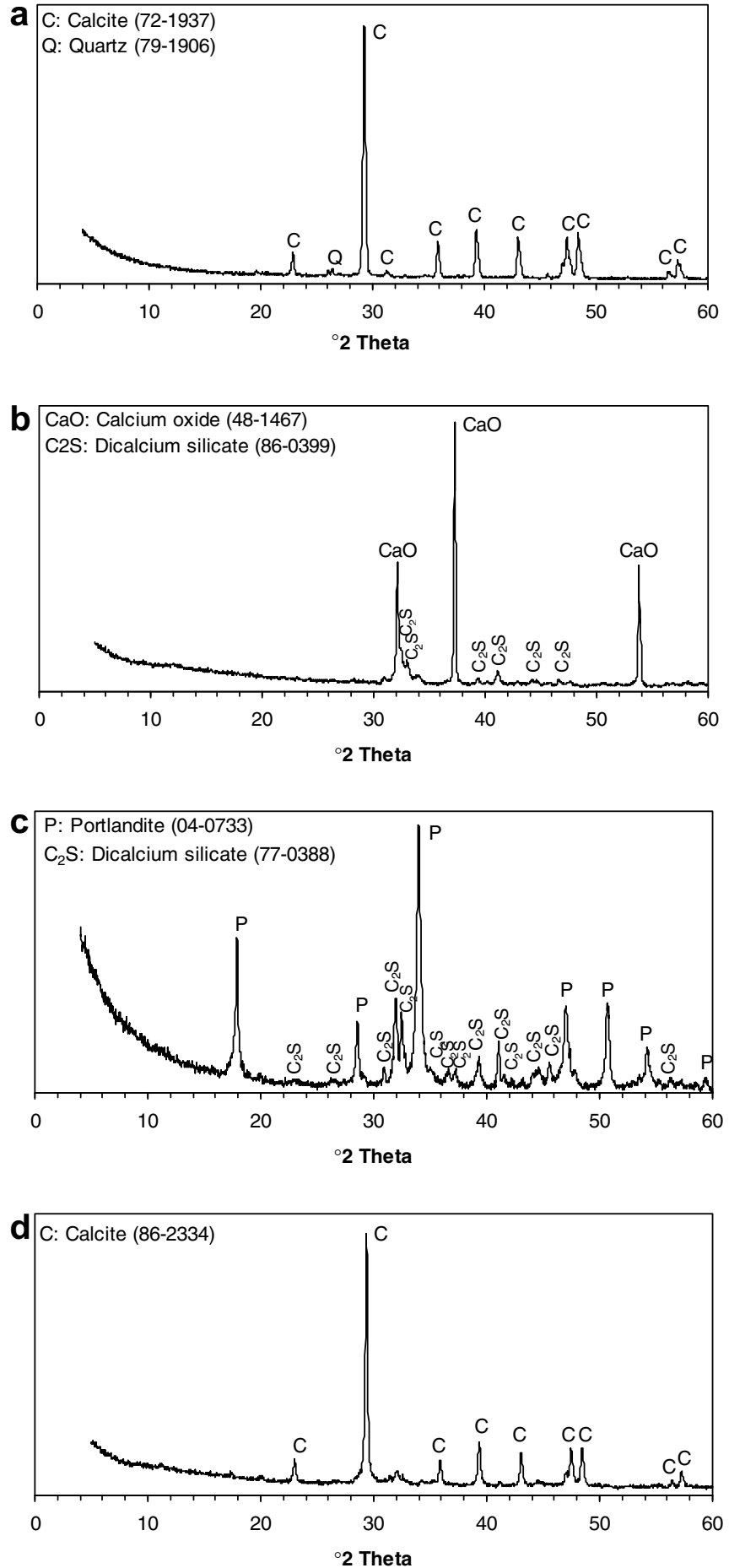

Fig. 9. XRD patterns of unheated limestone (a), heated limestone (b), slaked lime (c) and carbonated lime (d).
According to the cementation and hydraulic indices values of lime (Table 3), brick limes can be classified as moderately or highly hydraulic lime. However, the stone masonry limes are not hydraulic (except Ul-S lime), since their values are less than 0.1 .

Hydraulicity of white lumps can also be evaluated by thermal analysis (TGA). For this purpose, percentages of weight losses at $200-600{ }^{\circ} \mathrm{C}$ and at temperatures over $600{ }^{\circ} \mathrm{C}$ were determined on white lumps of brick and stone masonry mortars. Weight loss at temperatures of 200 $600{ }^{\circ} \mathrm{C}$ was mainly due to loss of chemically bound water of hydraulic products, such as calcium silicate hydrates and calcium aluminate hydrates [22]. Organic substances and hydrated salts, which also undergo weight losses in this temperature range, were not taken into consideration because they were not determined in the FTIR and XRD analyses. Weight loss at temperatures over $600{ }^{\circ} \mathrm{C}$ was due to carbon dioxide released during the decomposition of carbonates [22].

TGA analyses indicated that the weight loss between $200{ }^{\circ} \mathrm{C}$ and $600{ }^{\circ} \mathrm{C}$ was nearly $7 \%$ in the white lumps of brick masonry mortar (Fig. 6a), and $1.5 \%$ in the white lumps of stone masonry mortar (Fig. 6b). Weight loss over $600{ }^{\circ} \mathrm{C}$ was nearly $20 \%$ in the white lumps of the brick masonry mortars and $40 \%$ in the white lumps of the stone masonry mortars. These weight losses correspond to carbonated lime content nearly $50 \%$ in the white lumps of the brick masonry mortars, and $90 \%$ in the lumps found in the stone masonry mortars. It has been reported that if the ratio of $\mathrm{CO}_{2} / \mathrm{H}_{2} \mathrm{O}$ is between 1 and 10 in a given mortar, it can be accepted as a hydraulic lime mortar [7,23]. When this is adapted to the evaluation of the hydraulicity of lime, the $\mathrm{CO}_{2} / \mathrm{H}_{2} \mathrm{O}$ ratio is 3 for the white lumps of brick masonry mortars and 25 for the white lumps of the stone masonry mortars. This reveals that the lime used in the brick masonry mortars contains high percentages of structurally-bound water belonging to calcium silicate hydrates.

TGA analyses of their mortar matrices were also carried out in order to evaluate the contribution of aggregates to the hydraulicity of the mortars by producing hydraulic reaction products with their reaction with lime. The analyses reveal that the $\mathrm{CO}_{2} / \mathrm{H}_{2} \mathrm{O}$ ratios of the brick masonry

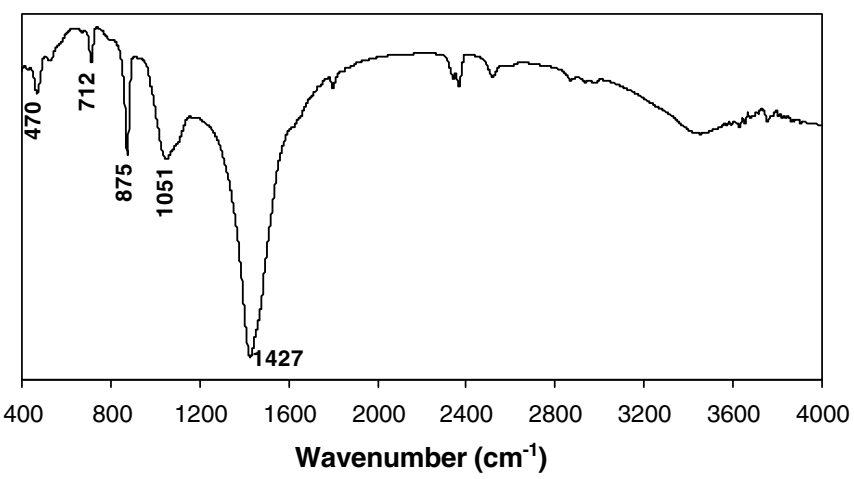

Fig. 10. Infrared spectrum of limestone containing diatomite. 
a
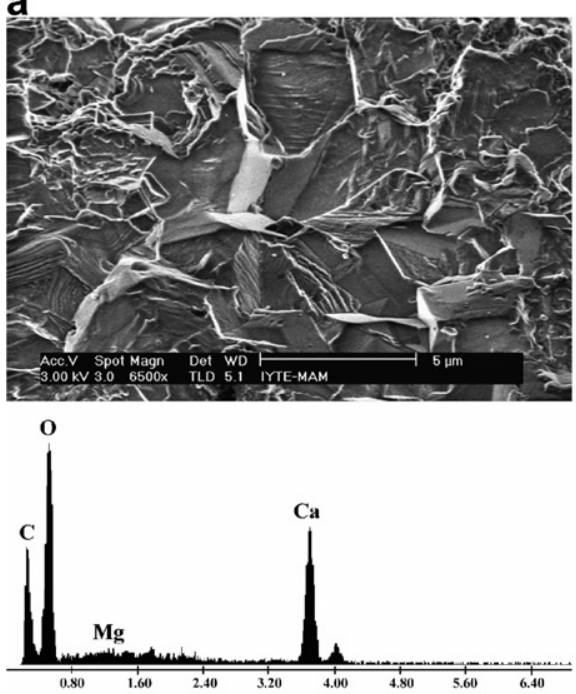

c
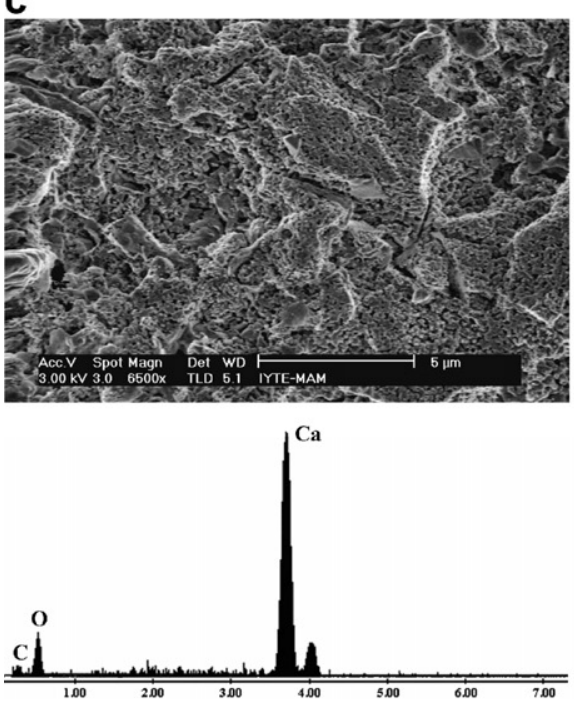

e
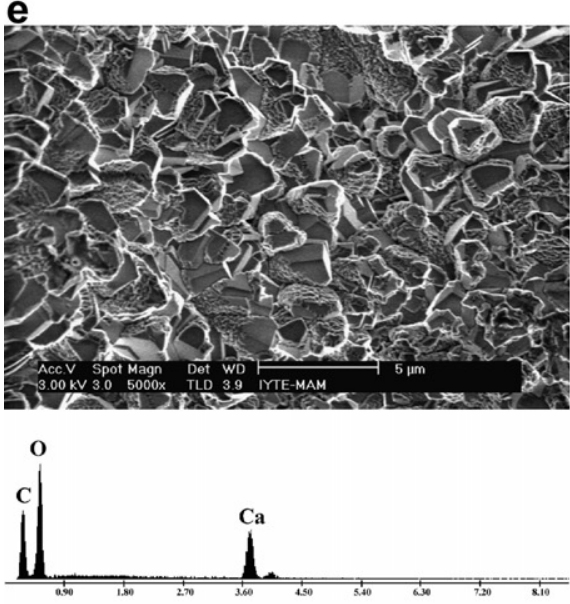

b
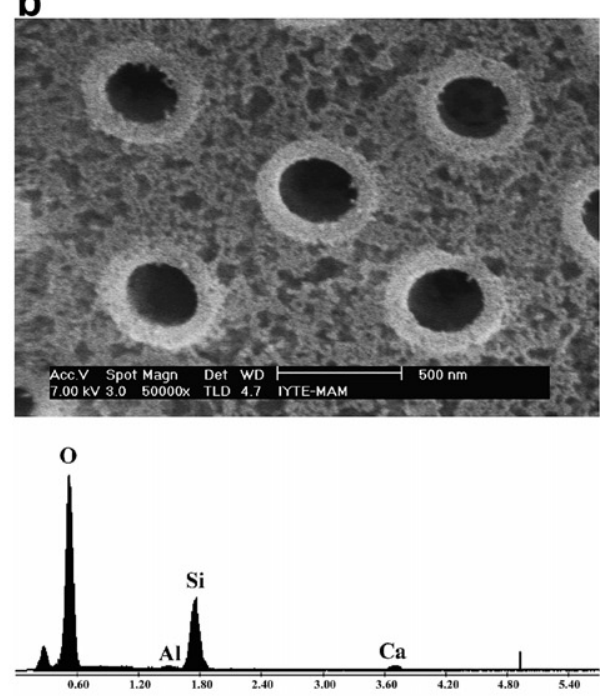

d
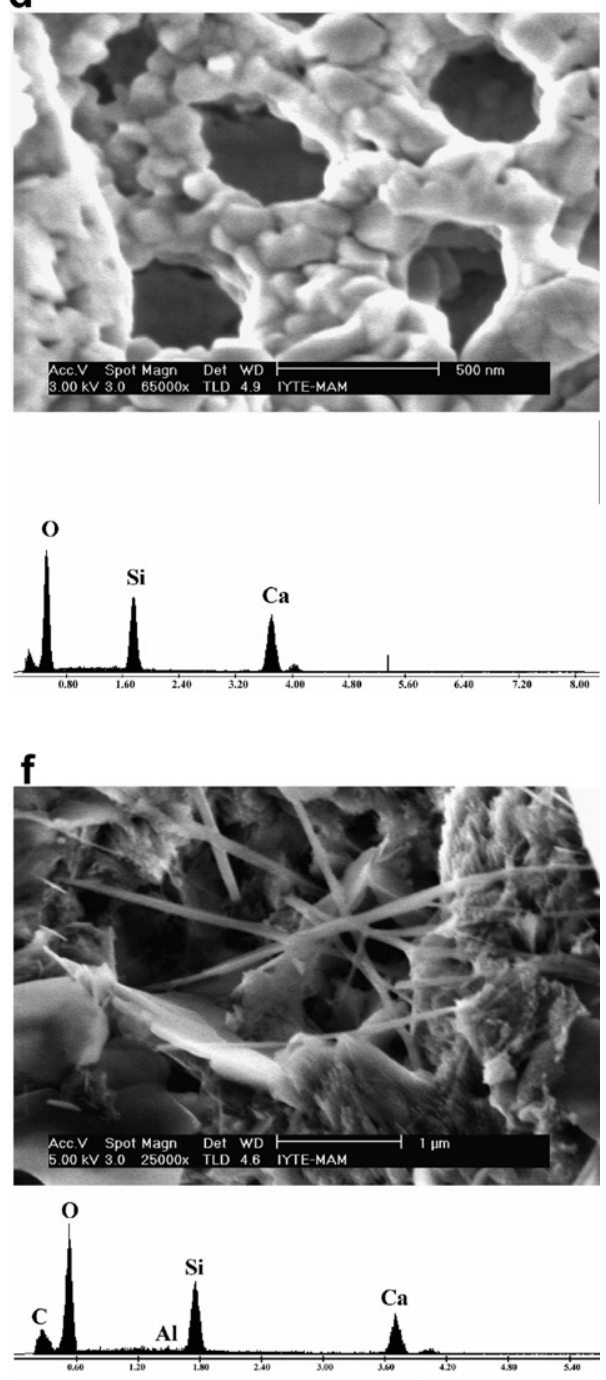

Fig. 11. SEM-EDS spectrums of calcite crystals in limestone (a); holes on a diatom (b); formed porous quicklime (c) formed C2S on the holes of diatom after heating of limestone (d); formed micritic calcite crystals (e) and fibrous network (f) after carbonation of lime. 
mortars were around 4, indicating their hydraulic character. However, the stone masonry mortars are not hydraulic, since their $\mathrm{CO}_{2} / \mathrm{H}_{2} \mathrm{O}$ ratio was more than 10 . These ratios show no significant difference between the white lumps and the mortar itself. In other words, the aggregates do not contribute significantly to the hydraulicity of the brick masonry mortars. Therefore, it can be deduced that the hydraulic character of the brick masonry mortars is derived from the use of hydraulic lime.

Considering the SEM-EDS, XRD, IR and TGA analysis results, it can be said that the lime used in the stone masonry mortars is high calcium lime. The observation of carbonate and silicon containing compounds in the IR, but the absence of the latter in the XRD patterns and the presence of fibrous network with high silica content, and low $\mathrm{CO}_{2} / \mathrm{H}_{2} \mathrm{O}$ ratio may show the hydraulic character of lime used in brick masonry mortars.

\subsection{Production of hydraulic lime from limestone containing diatoms}

As previously noted, hydraulic lime is obtained by the heating of limestone that contains quartz and clays, forming calcium and aluminum silicates at $950-1250{ }^{\circ} \mathrm{C}$ [5]. Larnite $\left(\mathrm{C}_{2} \mathrm{~S}\right)$ and Gehlenite $\left(\mathrm{C}_{2} \mathrm{AS}\right)$ are the major hydraulic phases of hydraulic lime [24]. Considering the types of kilns and fuels used in the 15th century when these baths were constructed, it may have been difficult to achieve such high kiln temperatures [25]. This study examines the possibility of obtaining hydraulic lime at a relatively low temperature.

A type of limestone used in the region where the baths are located contains high amounts of amorphous silica from diatoms. The same type of limestone is observed in some of the mortars as aggregate (Fig. 1). High silica content is also observed in the white lumps in the brick masonry mortars (Table 2). This may indicate that the lime used in the brick masonry mortars was manufactured from this type of limestone. To investigate this, limestone that contains diatoms was collected from walls of the historic Kamanl mosque, which is adjacent to the baths.

SEM-EDS analysis indicates that the limestone used in the walls of the mosque contains nearly $30 \%$ silicon oxide in its composition that is originated by the presence of the high amounts of diatoms (Fig. 7). Diatoms are composed of skeletal shells from many kinds of unicellular algae [26]. TGA analysis shows that the calcination temperature of limestone is around $800{ }^{\circ} \mathrm{C}$ (Fig. 8). Observation of a $31 \%$ weight loss due to carbon dioxide driven from the limestone at this temperature indicates that limestone contains nearly $70 \%$ calcite. There was no observed weight loss due to dehydroxylation of clay minerals between 400 and $600{ }^{\circ} \mathrm{C}$ on the TGA graph, which indicates that limestone does not contain clay minerals.

XRD analysis of the limestone shows that it is mainly composed of calcite minerals (Fig. 9a). However, in FTIR analysis silica-containing minerals $\left(1051,470 \mathrm{~cm}^{-1}\right)$ were observed in addition to calcite minerals $(1427,875$,
$712 \mathrm{~cm}^{-1}$ ) (Fig. 10). This supports that limestone is composed of calcite crystals and the amorphous silica originating from the diatoms.

The microstructure analysis of limestone shows that small and large grain size calcite crystals with diatoms are distributed inhomogeneously in the stone (Fig. 11a and b). After limestone was heated from ambient temperature to $850{ }^{\circ} \mathrm{C}$ for $12 \mathrm{~h}$ in a laboratory furnace, calcium oxide and calcium silicate peaks $\left(\mathrm{C}_{2} \mathrm{~S}\right)$ were identified by XRD analysis (Fig. 9b). SEM analysis presented that quicklime formed at this temperature has a porous structure due to carbon dioxide driven from the calcite minerals (Fig. 11c). Observation of mainly calcium and silicon peaks in the EDS spectrum of the diatoms may show that the diatoms are converted to $\mathrm{C}_{2} \mathrm{~S}$ by reaction with quicklime when heated to $850{ }^{\circ} \mathrm{C}$ (Fig. 11d).

The calcined limestone is slaked with water. After slaking process, calcium hydroxide (portlandite) and dicalcium silicate were indicated in the XRD patterns (Fig. 9c). This may suggest that the formation of calcium hydroxide is more favorable than the formation of calcium silicate hydrate. After the carbonation of lime with the presence of water in room conditions for one month, only calcium carbonate peaks were observed in the XRD patterns (Fig. 9d). Disappearance of calcium silicate peaks $\left(\mathrm{C}_{2} \mathrm{~S}\right)$ in the XRD patterns was explained by the formation of calcium silicate hydrate $(\mathrm{CSH})$ with water. The expected main XRD peaks of CSH were not observed in the carbonated lime. This was probably due to amorphous character of CSH or its principal peaks overlap with calcite [27]. SEM-EDS analysis indicated that carbonated lime was composed of micritic calcite crystals connected with fibrous network rich in silicon oxide (Fig. 11e and f).

Hydraulic (HI) and cementation (CI) indices of lime can be calculated according to Boynton formulas (Eq. (1) and (2)). Their HI and CI values were nearly 0.5 and 1.2 respectively (Table 2). High HI and CI results show that lime is hydraulic. Thermal analysis (TGA) was also carried out in order to evaluate the hydraulicity of the carbonated lime. TGA analyses data indicated that the weight loss between $200{ }^{\circ} \mathrm{C}$ and $600{ }^{\circ} \mathrm{C}$ was $6.4 \%$ and $25.6 \%$ over

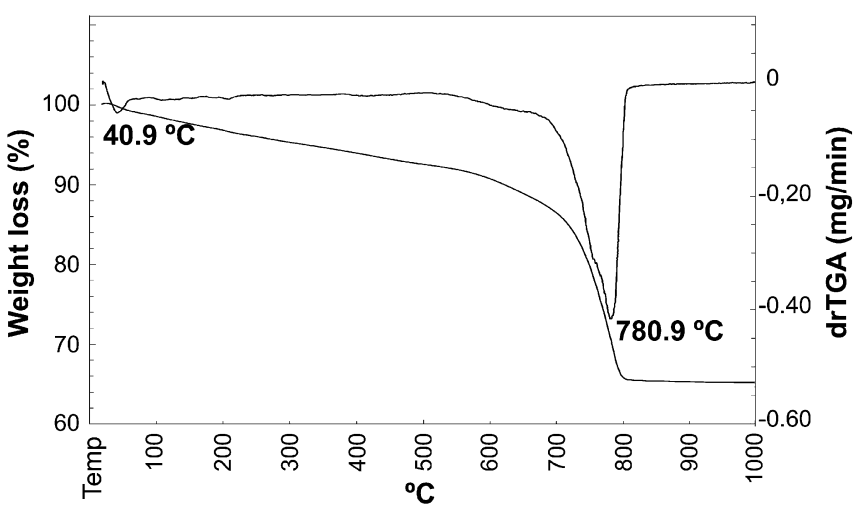

Fig. 12. TGA-drTGA graphs of carbonated lime produced by limestone containing diatoms. 
$600{ }^{\circ} \mathrm{C}$ (Fig. 12). These weight losses were mainly due to loss of chemically bound water of calcium silicate hydrates and calcium carbonates. The $\mathrm{CO}_{2} / \mathrm{H}_{2} \mathrm{O}$ ratio of lime is 4 , meaning that lime can be regarded as hydraulic.

\section{Conclusions}

In this study lime binder used in the stone and brick masonry mortars of some historic Ottoman baths was examined to understand whether the binders were hydraulic or not. The results of this study indicate that the lime binder used in the mortars of brick masonry of the baths is hydraulic. At the same time the brick masonry mortars were found to be relatively high in compressive strength.

Taking into account the kiln and fuel conditions of the 15 th century, the possibility of obtaining hydraulic lime by calcining limestone containing diatoms composed of amorphous silicon oxide at relatively low temperature was examined. The results show that the production of calcium silicate at a relatively low calcinations temperature $\left(850^{\circ} \mathrm{C}\right)$ is possible. Considering this result, it can be concluded that hydraulic lime could be produced by the calcining of limestone containing diatoms with 15 th century kiln conditions.

Further inquiries can be made to investigate the hydraulicity of lime under laboratory conditions by checking the compressive strengths of the mortars that are prepared using lime produced from limestone containing diatoms.

\section{Acknowledgments}

The authors thank the researchers of the Centre for Materials Research at the İzmir Institute of Technology for XRD and SEM-EDS analyses during the experimental stage of this study.

\section{References}

[1] Davey N. A history of buildings materials. London: Phoenix House; 1961.

[2] Cowan HJ. The master builders: a history of structural and environmental design from ancient Egypt to the nineteenth century. New York: John Willey \& Sons; 1977.

[3] Middendorf B, Knöfel D. Characterization of historic mortars from buildings in Germany and the Netherlands. In: Baer NS, Fitz S, Livingston RA, editors. Conservation of historic brick structures. Dorset: Donhead Publishing; 1998. p. 179-95.

[4] Vicat LJ. Mortars and cements. Shaftesbury: Donhead publishing; 1997.

[5] Lea FM. The chemistry of cement and concrete. London: Edward Arnold Ltd.; 1970.

[6] Hansen EF, Balen KV, Elert K, Rodriquez-Navarro C, Simon S. Preservation of lime mortars and plasters. The GCI Project Bibliographies Series, 2003.
[7] Moropoulou A, Bakolas A, Bisbikou K. Investigation of the technology of historic mortars. J Cult Herit 2001(1):45-58.

[8] Ingo GM, Fragala I, Bultrini G, Caro T, Riccucci C, Chiozzini G. Thermal and microchemical investigation of Phoenician-Punic mortars used for lining cisterns at Tharros (western Sardinia, Italy). Thermochim Acta 2004(418):53-60.

[9] Degryse P, Elsen J, Waelkens M. Study of ancient mortars from Sagalassos (TURKEY) in view of their conservation. Cement Concrete Res 2002;32:1457-63.

[10] Moropoulou A, Tsiourva Th, Bisbikou K, Biscontin G, Bakolas A, Zendri E. Hot lime technology imparting high strength to historic mortars. Constr Build Mater 1996;10(2):151-9.

[11] Güleç A, Tulun T. Studies of old mortars and plasters from the Roman, Byzantine and Ottoman period of Anatolia. Arch Sci Rev 1996:3-13

[12] Franzini M, Leoni L, Lezzerini M, Sartori F. On the binder of some ancient mortars. Mineral Petrol 1999(67):59-69.

[13] Büyükdigan I. A critical look at the new functions of Ottoman baths. Build Environ 2003(38):617-33.

[14] Reyhan K. Construction techniques and materials of the Ottoman period baths in Seferihisar-Urla region. Izmir: MS thesis, Department of Architectural Restoration, Izmir Institute of Technology, 2004.

[15] RILEM. Tests defining the structure. Mater Constr 1980(13):73.

[16] Teomete E. Finite element modeling of historical masonry structures; case study: Urla Kamanlı Mosque. İzmir: MS thesis, Department of Civil Engineering, İzmir Institute of Technology, 2004.

[17] Livingston R. Materials analysis of the masonry of the Hagia Sophia Basilica. In: Brebbia CA, Frewer RJB, editors. Structural repair and maintenance of historic buildings. Southampton: Computational Mechanics Publications; 1993. p. 15-32.

[18] Bruni S, Cariati F, Fermo P, Cairati P, Alessandrini G, Toniolo L. White lumps in fifth-to seventeenth-century $\mathrm{AD}$ mortars from northern Italy. Archaeometry 1997;39(1):1-7.

[19] Bakolas A, Biscontin G, Moropoulou A, Zendri E. Characterization of the lumps in the mortars of historic masonry. Thermochim Acta 1995;269(270):809-16.

[20] Yu P, Kirkpatrick RJ, Poe B, McMillan PF, Cong X. Structure of calcium silicate hydrate $(\mathrm{C}-\mathrm{S}-\mathrm{H})$ : near-, mid-, and far-infrared spectroscopy. J Am Ceram Soc 1999;82(3):742-8.

[21] Gadsden JA. Infrared spectra of minerals and related inorganic compounds. Sussex: Butterworth; 1975.

[22] Bakolas A, Biscontin G, Contardi V, Franceschi E, Moropoulou A, Palazzi D, et al. Thermoanalytical research on traditional mortars in Venice. Thermochim Acta 1995;269(270):817-28.

[23] Moropoulou A, Bakolas A, Bisbikou K. Physico-chemical adhesion and cohesion bonds in joint mortars imparting durability to the historic structures. Constr Build Mater 2000;14:35-46.

[24] Callebaut K, Elsen J, Van Balen K, Viane W. Nineteenth century hydraulic restoration mortars in the Saint Michael's Church (Leuven, Belgium) natural hydraulic lime or cement. Cement Concrete Res 2001;31:397-403.

[25] Moropoulou A, Bakolas A, Aggelakopoulou E. The effects of limestone characteristics and calcination temperature to the reactivity of the quicklime. Cement Concrete Res 2001;31:633-9.

[26] Korunic Z. Diatomaceous earths, a group of natural insecticides. J Stored Res 1998;34:87-97.

[27] Luxan MP, Dorrego F. Ancient XVI century mortar from the Dominican Republic: its characteristics, microstructure and additives. Cement Concrete Res 1996;26:841-9. 